\title{
Community composition and extracellular enzyme activity of bacteria associated with suspended and sinking particles in contrasting arctic and sub-arctic marine environments
}

\author{
Tobias Tamelander* \\ Department of Arctic and Marine Biology, University of Tromsø, 9037 Tromsø, Norway
}

Present address: Institute of Marine Sciences, CSIC, Pg Maritim de la Barceloneta 37-49, 08003 Barcelona, Catalonia, Spain

\begin{abstract}
Heterotrophic bacteria contribute to controlling the oceans' biological carbon pump by solubilising organic particles and by using the dissolved organic matter for growth. To better understand how bacteria colonise and degrade vertically exported organic matter, spatial and temporal variations in the bacterial community composition (BCC) and cell-specific extracellular enzyme activity were investigated in water column samples and in sinking material collected by short-term deployed sediment traps in the Barents Sea (Arctic Ocean) and in a North-Norwegian fjord. Denaturing gradient gel electrophoresis showed that both the suspended and sinking BCC differed among locations (Arctic Water, Atlantic Water and fjord) and with time (summer vs. autumn in the fjord). Within stations, the BCC differed between shallow (20 to $50 \mathrm{~m}$ ) and deep (120 or $200 \mathrm{~m}$ ) suspended samples. The sediment traps revealed no depth-related difference but had high similarity to the shallow suspended samples, indicating that the exported community largely derived from suspended particles in the upper mixed layer and that little new colonisation or succession of the resident community took place during transfer to depth. Bacteria in the sediment traps tended to have higher enzyme activities compared to suspended bacteria, likely reflecting a response to aggregation and different composition (carbon, nitrogen and chlorophyll) of suspended and sinking organic matter. While the present study demonstrates that particle export from the surface layer contributes to microbial diversity in the deep sea, future studies using high taxonomical resolution are required to further evaluate the importance of this dispersal pathway.
\end{abstract}

KEY WORDS: Marine particles · Sediment traps · Bacterial community composition · DGGE · Extracellular enzyme activity $\cdot$ Arctic Ocean $\cdot$ Barents Sea $\cdot$ Fjord

\section{INTRODUCTION}

Bacterial dissolution and degradation of particles is an important process in the cycling of organic matter in the ocean. Because particles are the primary vehicles for vertical export of organic material from the oceans' productive surface layer to the deep sea, bacteria associated with marine particles contribute to the export of organic matter and to the regulation of its magnitude and composition (Turley \& Mackie 1995). Studies based on size-fractionation of water column suspended samples have shown that particle-associated bacterial communities differ in composition from free-living communities (DeLong et al. 1993, Kellogg \& Deming 2009) and that particle-associated bacteria are metabolically more active and have higher growth rates than free-living bacteria (Smith et al. 1992, Huston \& Deming 2002, Baltar et 
al. 2010). Large particles, such as aggregates, zooplankton faecal pellets and algal resting stages, are not efficiently sampled by standard water bottle techniques due to their high sinking speed, and therefore tend to be overrepresented in sediment trap samples compared to water bottle samples (Wassmann et al. 1999, Spilling et al. 2006). These important components of the biological carbon pump may host a characteristic bacterial biota (Ditchfield et al. 2012, Jing et al. 2012), which is overlooked in studies focusing on water column suspended particles alone.

Field studies of bacteria associated with vertically exported material collected in sediment traps have largely focused on total bacterial abundance, BA (Turley \& Mackie 1995), or on the flux of cyanobacteria vs. eukaryotic protists (Amacher et al. 2013). Bacterial solubilisation of sinking particles directly impacts the composition and magnitude of the vertically exported material, but investigations of the metabolic activity of bacteria in sediment traps are scarce and reveal conflicting results from comparable marine environments. While Huston \& Deming (2002) found higher cell-specific hydrolytic enzyme activity and a higher proportion of actively respiring bacteria in sediment trap samples from the Baffin Bay, Tammert et al. (2008) found an equal contribution of actively respiring bacteria in sediment traps and ambient water samples in the Barents Sea. The community composition and source of total bacteria associated with sinking material as well as the temporal and geographical variation in the composition and activity of these communities largely remains unknown, and knowledge of how bacteria impact the biological carbon pump is therefore incomplete.

Modelling and experimental work reveal that motile bacteria colonise particles faster than nonmotile bacteria and that rapid exchange between attached and free bacteria occurs as a result of attachment and detachment from aggregates (Kiørboe et al. 2002). While BA on suspended particles may reach steady state within only $2 \mathrm{~h}$ (Kiørboe et al. 2003), particles sinking through the water column are exposed to different ambient communities and may undergo multiple colonisations, resulting in community shifts over time and with increasing depth. In the deep sea, pressure may act as a selective force with increasing depth. Incubations of particles retrieved from sediment traps revealed an increase in the proportion of Bacteria over Archaea over time in treatments exposed to pressure equivalent to $1500 \mathrm{~m}$ depth (Tamburini et al. 2009), suggesting that changes in the community may take place during sinking, at least through abyssal regions. Methanogenic bacterial taxa were recently discovered in sediment trap samples in a Scottish loch and in zooplankton faecal pellets from the same location (Ditchfield et al. 2012), supporting earlier findings that these taxa proliferate on large marine particles and sinking organic particles (Karl \& Tilbrook 1994, Marty et al. 1997).

The bacterial community composition (BCC) and extracellular enzyme activity was investigated in sinking particulate organic matter (collected by sediment traps) and in the ambient water column in contrasting environments represented by a NorthNorwegian fjord (Balsfjord) and the Barents Sea (Arctic Ocean). Characteristic of high-latitude environments, large fast-sinking particles such zooplankton faecal pellets typically contribute significantly to the downward flux of organic matter in these regions (Wexels Riser et al. 2010, Tamelander et al. 2012). It was hypothesised that (1) the sediment trap samples would reveal similar bacterial communities across locations, characterized by different water masses and between seasons. It was further hypothesised that (2) the community on sinking particles would change with depth as a result of succession of the dominant groups over time. The sediment traps were assumed to host a higher fraction of particle-associated bacteria than the ambient water column, leading to the hypothesis (3) that bacteria in sediment traps would have higher cell-specific extracellular enzyme activity, reflecting the high metabolic activity of particle-associated bacteria.

\section{MATERIALS AND METHODS}

\section{Study area}

Field sampling was carried out in the north Norwegian fjord Balsfjord (sampling position $69^{\circ} 22.0^{\prime} \mathrm{N}$, $19^{\circ} 7.0^{\prime} \mathrm{E}$ ) in April, June and October 2010, and in the Barents Sea in June 2011 (Fig. 1). The fjord receives freshwater from rivers and from snowmelt in spring. Water exchange between the fjord and the shelf, dominated by more saline Atlantic-influenced Norwegian Coastal Water, is restricted by a ca. $30 \mathrm{~m}$ deep sill (Eilertsen \& Skardhamar 2006). In the Barents Sea, the 3 stations visited were positioned in $\mathrm{N}$ to $\mathrm{S}$ direction across the polar front and therefore dominated by different water masses (Fig. 1). Stns M1 (78 5.8 N, $\left.28^{\circ} 7.6^{\prime} \mathrm{E}\right)$ and $\mathrm{M} 2\left(76^{\circ} 57.0^{\prime} \mathrm{N}, 29^{\circ} 42.7^{\prime} \mathrm{E}\right)$ had partial ice-cover (40 to $70 \%$ and 10 to $40 \%$, respectively), while Stn M4 $\left(74^{\circ} 54.6^{\prime} \mathrm{N}, 30^{\circ} 0^{\prime} \mathrm{E}\right)$ was outside the 


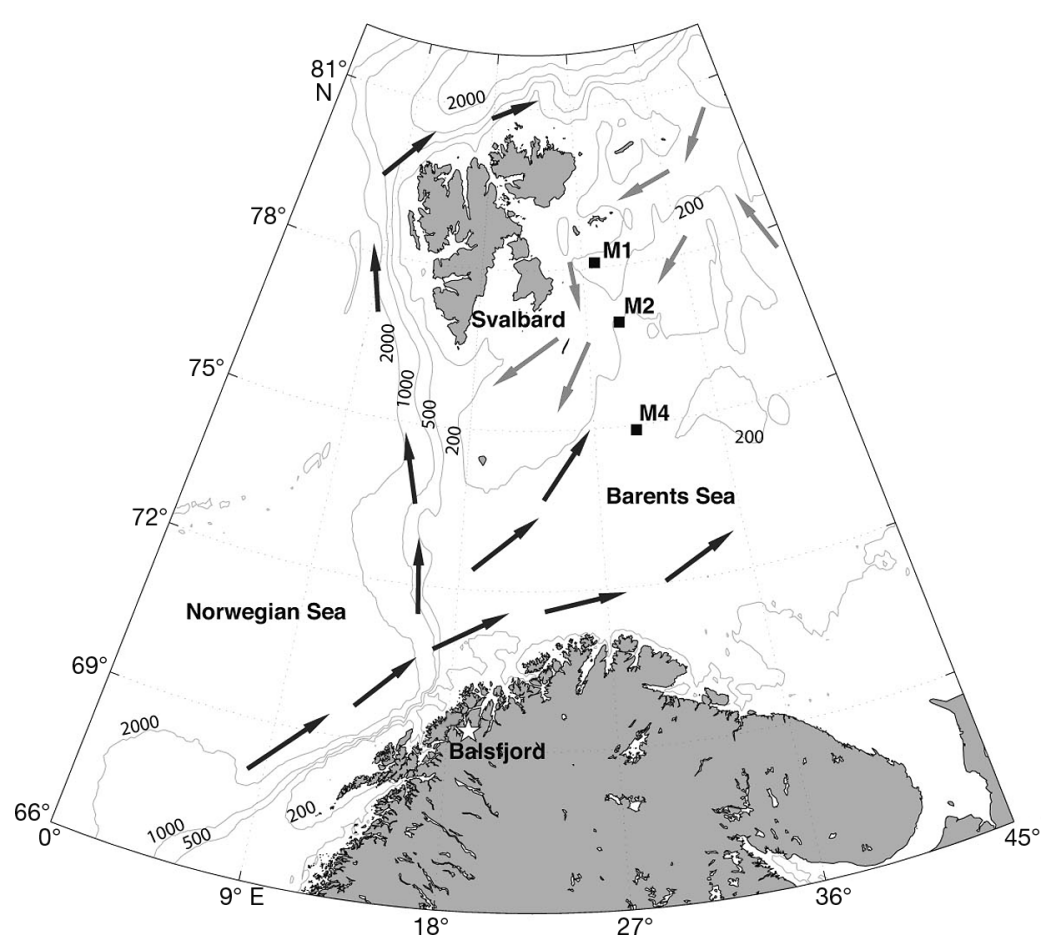

Fig. 1.North Norwegian coast and the Barents Sea with sampling locations in 2010 (Balsfjord, white star) and in June 2011 (Stns M1, M2 and M4). Grey lines: bathymetry (m). Arrows: main (black) Atlantic Water and (grey) Arctic Water currents

seasonal extent of sea ice. Descriptions of the water masses and ice conditions in the Barents Sea can be found in Loeng (1991) and Sundfjord et al. (2007).

\section{Sample collection, bacterial abundance and biochemical analyses}

Standard CTD casts were obtained at each station. Water samples for suspended particulate organic matter were collected with Niskin bottles, and sinking particles were collected by sediment traps deployed for ca. $24 \mathrm{~h}$ without fixatives. The sediment traps (KC Denmark A/S) consisted of parallel cylinders with a height:diameter ratio of 6.25 and a volume of $1.8 \mathrm{l}$, mounted in a gimballed frame equipped with a vane. An array of 8 sediment traps positioned at fixed depths between 20 and $120 \mathrm{~m}$ (fjord) or $200 \mathrm{~m}$ (Barents Sea) was deployed. Upon deployment, the sediment traps became filled with ambient seawater and therefore received a background of suspended organic matter and bacteria. No correction was made for this background because it was considered to be small compared to the material accumulated in the traps during deployment. Upon retrieval, the contents of the 2 cylinders from each depth were combined to form 1 sample. An aliquot of $250 \mathrm{ml}$ was collected for bacterial parameters after mixing the original sample by gently turning the bottle several times. From this sample, smaller volumes were drawn by pipette for BA, enzyme assays and DNA extraction. BA and enzyme activity were determined at 4 depths in both sample types (suspended and sediment traps), with 1 sample taken from the depth of maximum fluorescence and from the closest sediment trap (see Table 1). The BCC was determined at 2 depths. In the fjord, the sediment trap array was anchored to the seabed, and in the Barents Sea, a free-drifting array tethered to a drifter at the surface was used.

Samples for BA were fixed with fresh formaldehyde to a final concentration of $2 \%$ and filtered directly without further treatment (e.g. sonication) onto black $0.2 \mu \mathrm{m}$ pore size membrane filters. The filters were stained with DAPI and mounted on slides which were stored at $-20^{\circ} \mathrm{C}$ until BA was obtained using an epifluorescence microscope. One sample was analysed from each depth, and minimum of 10 frames and 500 cells were counted in each sample. BA is considered to reflect the total abundance since no size-fractionation was performed to quantify free and attached bacteria separately.

Samples for analyses of the BCC by denaturing gradient gel electrophoresis (DGGE) were collected at 2 depths: one corresponding to the depth of maximum fluorescence and at $120 \mathrm{~m}$ (fjord) or $200 \mathrm{~m}$ depth (Barents Sea). Between 50 and $150 \mathrm{ml}$ of sample aliquots were filtered within a few hours after water-bottle or sediment-trap retrieval, through polycarbonate membrane filters with $0.2 \mu \mathrm{m}$ pore size (Whatman). One sample was prepared from each depth, and the filters were stored at $-20^{\circ} \mathrm{C}$ in sucrose buffer $(40 \mathrm{mM}$ EDTA, $50 \mathrm{mM}$ Tris $[\mathrm{pH}=8]$ and $0.75 \mathrm{M}$ sucrose) until processed further. April samples from the fjord were frozen without buffer, and amplification of these samples by polymerase chain reaction (PCR) failed. From the Barents Sea, samples were analysed from Stns M1 (Arctic Water) and M4 (Atlantic Water), representing end-members of the environmental gradient. Because no size-fractionation was performed, the samples represent the total bacterial community including both particle-associated and free-living bacteria. 
Sampling and analyses of particulate organic carbon (POC) and nitrogen (PON) followed Reigstad et al. (2008). Briefly, sample aliquots were filtered through glass fibre filters (GF/F) and stored frozen until processed further. $\mathrm{C}$ and $\mathrm{N}$ content was determined on a CHN elemental analyser after the samples had been dried $\left(60^{\circ} \mathrm{C}\right.$ overnight) and exposed to $\mathrm{HCl}$ fumes to remove inorganic carbon.

Chlorophyll a ( $\mathrm{chl}$ a) concentration was determined both for the total community and for the $>10 \mu \mathrm{m}$ size fraction by filtering samples through GF/F filters and $10 \mu \mathrm{m}$ pore size membrane filters, respectively. Chl a was determined on board according to Holm-Hansen \& Riemann (1978) using methanol extraction. For details of sampling and extraction, see Reigstad et al. (2008). Chl a data are not available from the sediment traps at Stn M4 due to contamination of these samples.

\section{Extracellular enzyme assays}

Extracellular enzyme activity (EEA) was determined using fluorescence-labelled artificial substrates following the method of Hoppe (1983). The activities of $\beta$-glucosidase (BG) and leucine-aminopepotidase (LAP) were assessed in triplicate using 4-methylumbelliferyl-b-D-glucoside and L-leucine 7-amido-4methylcoumarin as substrates, respectively. Assays were performed on the total material without sizefractionation at saturating substrate concentrations (200 $\mu$ mol substrate $1^{-1}$ ), determined in saturation experiments beforehand, yielding maximum EEA. In the Barents Sea, the incubation volume was $5 \mathrm{ml}$, and fluorescence was detected with a Turner Designs 10 AU fluorometer with excitation at $365 \mathrm{~nm}$ and emission at $436 \mathrm{~nm}$. In Balsfjord, incubations were performed in 96-well plates with a sample volume of $0.4 \mathrm{ml}$, and fluorescence was determined on a plate reader fluorometer (Molecular Devices Spektromax Gemini) at excitation and emission wavelengths of 355 and $460 \mathrm{~nm}$, respectively. Fluorescence was converted to substrate concentration using calibration curves prepared from 4-methylumbelliferyl (for BG) and 7-amido-4-methylcoumarin (for LAP). The samples were mixed by inverting the tubes (Barents Sea) or by shaking the 96-well plates automatically in the plate reader (fjord) prior to fluorescence readings, and the samples were incubated without mixing in temperature-controlled rooms at close-to in situ temperature until a significant increase in fluorescence was recorded. Incubation time never exceeded $12 \mathrm{~h}$ to minimize effects of eventual changes in the BCC and to avoid substrate limitation and oxygen depletion. EEA was calculated from 2 fluorescence recordings and blank-corrected for fluorescence in heat- or formalin-killed controls. EEA obtained with only start and end measurements did not differ from trials with 5 readings and regression-based determination of EEA. Some assays gave a slight decrease in fluorescence, yielding negative EEA; in these, EEA was assumed to be zero. BG and LAP were normalised to BA to obtain cell-specific rates (amol substrate $\mathrm{h}^{-1}$ cell $\left.^{-1}\right)$.

\section{DNA extraction and molecular analyses}

Nucleic acids were extracted using a $\mathrm{MO}$ BIO UltraClean Soil DNA Isolation kit (MO BIO Laboratories), following the provided instructions. Samples were quantified and quality checked using a NanoDrop spectrophotometer (Thermo Scientific). Amplifications of $16 \mathrm{~S}$ rRNA gene fragments were performed with the touchdown PCR procedure using a Bio-Rad thermocycler (Bio-Rad). To perform DGGE amplifications, the following primers designed by Muyzer et al. (1997) were used: 358f-GC 5'-CCT ACG GGA GGC AGC AG-3' (target group: bacteria; with a $40 \mathrm{bp}$ GC-clamp sequence attached to the 5' end) and 907RM 5'-CCG TCA ATT CMT TTG AGT TT-3'. The PCR mixtures $(50 \mu l)$ each contained $5 \mu \mathrm{l}$ of extracted DNA as a template, $1 \mu \mathrm{l}$ of deoxynucleoside triphosphate mix at a concentration of $10 \mathrm{mM}$ each, $2 \mu \mathrm{l}$ of $\mathrm{MgCl}_{2}$ (25 mM solution), $5 \mu \mathrm{l}$ of BSA $\left(3 \mathrm{mg} \mathrm{ml}^{-1}\right.$ ), $5 \mu \mathrm{l}$ of PCR buffer (Invitrogen), $2.5 \mu \mathrm{l}$ of each primer at a concentration of $10 \mu \mathrm{M}, 0.25 \mu \mathrm{l}$ of Taq DNA polymerase (Invitrogen) and $27 \mu \mathrm{l}$ of $0.2 \mu \mathrm{m}$-filtered sterilized water. The PCR program included an initial denaturation at $94^{\circ} \mathrm{C}$ for $5 \mathrm{~min}$, followed by 10 cycles of denaturation at $94^{\circ} \mathrm{C}$ for $1 \mathrm{~min}$, annealing at $65^{\circ} \mathrm{C}$ for $1 \mathrm{~min}$ (decreased by $1^{\circ} \mathrm{C}$ every cycle until $55^{\circ} \mathrm{C}$, at which an additional 20 cycles were carried out), and extension at $72^{\circ} \mathrm{C}$ for $3 \mathrm{~min}$, with a final extension cycle at $72^{\circ} \mathrm{C}$ for $10 \mathrm{~min}$. An aliquot of the PCR product was separated by electrophoresis in a $1 \%$ agarose gel and compared to a standard (Low DNA Mass Ladder; Invitrogen) as a quality control (visual inspection). All 16 samples and the standard were loaded in the same gel for the DGGE.

DGGE was performed with a DGGE-2000 system (CBS Scientific Company). Electrophoresis was performed with a $0.75 \mathrm{~mm}$ thick $6 \%$ polyacrylamide gel (acrylamide:bisacrylamide ratio of 37:5:1) submerged in $1 \times$ TAE buffer (40 mM Tris base, $20 \mathrm{mM}$ acetic acid and $1 \mathrm{mM}$ EDTA, pH 7.4) at $60^{\circ} \mathrm{C}$. 
Approximately $800 \mathrm{ng}$ of PCR product from environmental samples were applied to individual lanes in the gel. The gel was run at $100 \mathrm{~V}$ for $16 \mathrm{~h}$ in a linear 40 to $80 \%$ denaturant agent gradient $(100 \%$ denaturant agent was defined as $7 \mathrm{M}$ urea and $40 \%$ deionised formamide). The gels were stained for $45 \mathrm{~min}$ in $1 \times$ TAE buffer with Sybr-Gold nucleic acid stain (Invitrogen) and visualized with UV radiation using a Chemidoc system (Bio-Rad). Digitized DGGE images were analysed using the Quantity One software (BioRad). Similarities of the resulting band patterns were assessed by constructing a matrix taking into account the intensity of individual bands in each sample.

\section{Statistical analyses}

Hierarchical clustering of the DGGE data was used to investigate patterns in the BCC. Band intensity was expressed as the percentage of the row (band) total, and the data were arcsine and square root transformed to calculate Bray-Curtis dissimilarities among samples. The cluster analysis was performed in R (www.r-project.org). The relationship between $\mathrm{BCC}$ and environment was assessed by canonical correspondence analysis (CCA) based on chi-squared distances using the package 'vegan' in R. The environmental data (temperature, salinity, POC:PON ratio, POC:chl ratio and proportion of chl $a>10 \mu \mathrm{m}$ ) were centred and standardized prior to the CCA. The sediment trap sample from Stn M4 was excluded due to missing chl a data. The significance of the CCA was assessed by a permutation test with 199 permutations. An ANOVA of log-transformed cell-specific BG and LAP with Tukey's post hoc test was performed with station as predictive parameter because the untransformed data were not normally distributed. Substrate preference was assessed by comparing the cell-specific BG and LAP activity in sediment trap samples and in the water column by means of Mann-Whitney $U$-tests on untransformed data.

\section{RESULTS}

\section{Differences in water mass, stratification, and chl $a$ among stations}

The physical properties of the water column revealed distinct features at each station, representing 3 main water masses: fjord/coastal water influenced by freshwater runoff from land, Arctic water and Atlantic water (Fig. 2). The fjord station further underwent seasonal changes in temperature and water column stratification. In April, the water column in the fjord was nearly homogeneous with depth, with temperatures between 2.1 and $2.7^{\circ} \mathrm{C}$ and salinities between 33.3 and 33.9 (Fig. 2A). In June, a thin layer of relatively fresh (28.5) water in the uppermost $2 \mathrm{~m}$ had developed, and the temperature had increased to ca. $8^{\circ} \mathrm{C}$ at the surface. By October, the surface water salinity had increased to 32 , and the temperature was ca. $6^{\circ} \mathrm{C}$ and slightly lower than at $20 \mathrm{~m}$ depth. At $120 \mathrm{~m}$ depth, the tem-

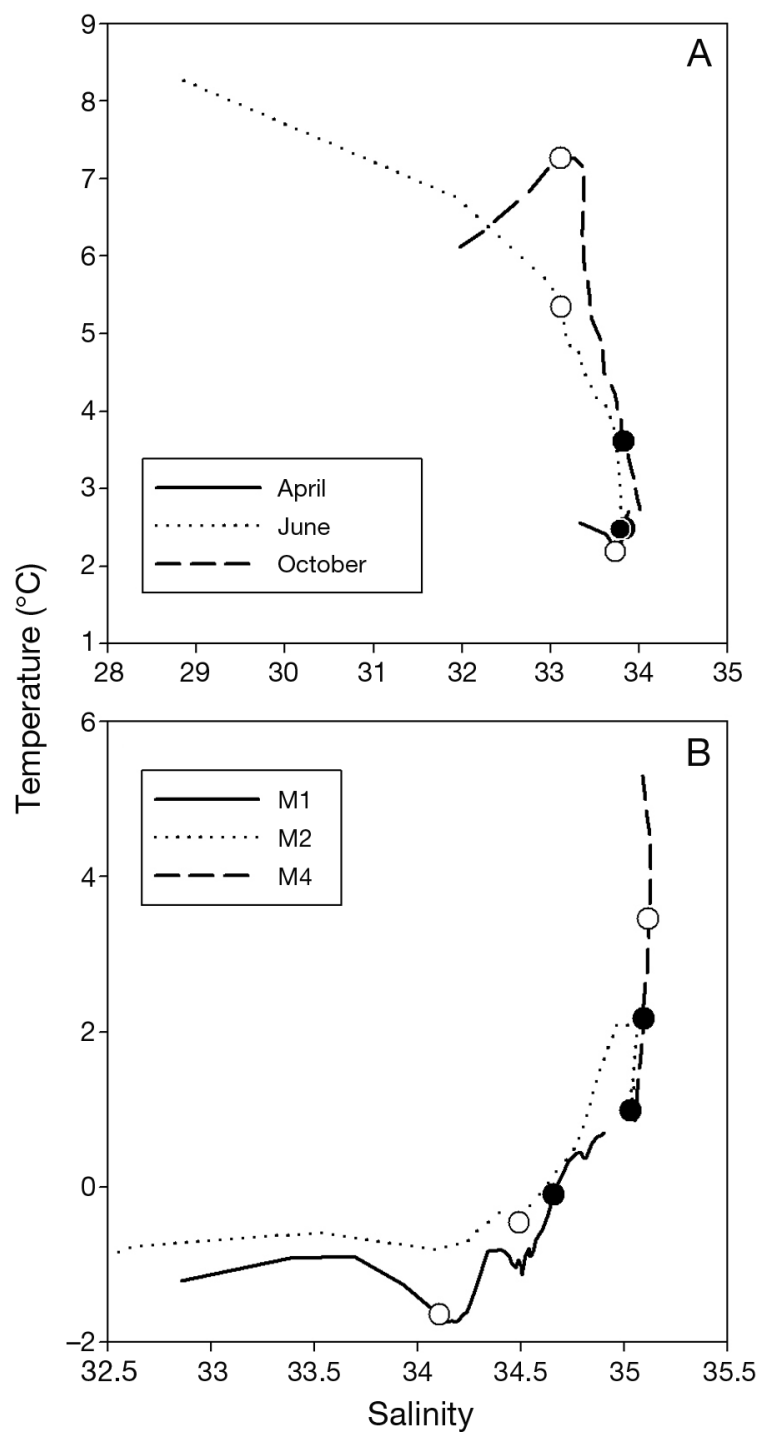

Fig. 2. Temperature-salinity plots from the stations in (A) Balsfjord and (B) the Barents Sea. Open symbols: depth of maximum fluorescence; filled symbols: $120 \mathrm{~m}$ (the fjord) or $200 \mathrm{~m}$ (Barents Sea) depth, corresponding to sampling depths for bacterial community. In (A), the symbols for deep samples in April and June are overlapping. Data were bin-averaged for $5 \mathrm{~m}$ intervals for clarity 
perature was more stable and remained between 2.5 and $3.6^{\circ} \mathrm{C}$ during the whole period (Fig. 2A). The chl a concentrations at the depth of maximum fluorescence were 1.6, 1.3 and $0.3 \mathrm{mg} \mathrm{m}^{-3}$ in April, June and October, respectively.

Stn M1 in the Barents Sea had temperatures between -1.7 and $-0.8^{\circ} \mathrm{C}$ and salinities between 32.9 and 34.2 to ca. $80 \mathrm{~m}$ depth, reflecting the Arctic water dominance at this station (Fig. 2B). Below this depth, a gradual increase in temperature and salinity indicated intrusion of water of Atlantic origin. Stn M2 was located over the polar front, with the cold and relatively fresh surface layer extending to ca. $50 \mathrm{~m}$ depth on top of warmer $\left(>1^{\circ} \mathrm{C}\right)$ and more saline Atlantic Water (Fig. 2B). The temperature at Stn M4 was between ca. $5^{\circ} \mathrm{C}$ at the surface and $0.5^{\circ} \mathrm{C}$ near the bottom $(371 \mathrm{~m})$, and salinity was above 35 throughout the water column, characteristic of Atlantic water (Fig. 2B). Maximum chlorophyll concentrations were 2.3, 1.4 and $1.6 \mathrm{mg} \mathrm{m}^{-3}$ at Stns M1, M2 and M4, respectively.

\section{Patterns in bacterial community composition}

The BCC was analysed in samples from the Arctic Stn M1 and from the Atlantic Stn M4 in the Barents Sea, representing end-members of the environmental gradient. Because amplification of the fjord samples from April failed, only the June and October samples were analysed. A total of 80 individual bands (on average, 25 bands per sample), corresponding to particular operational taxonomical units, were identified in the DGGE. Most bands occurred in both sample types (suspended and sediment traps). A total of 18 bands were unique to $\geq 1$ of the suspended samples, and 12 were unique to at least 1 sediment trap sample. Within stations, the number of bands per sample was slightly higher in the deep suspended samples (26 to 31 ) than at the depth of the maximum fluorescence (13 to 30), whereas the deep sediment traps usually had a lower number of bands (17 to 29) than the shallow-positioned traps (22 to 32). Stns M1 and M4 and the June sample from the fjord revealed a higher number of bands in the shallow sediment trap than the corresponding suspended sample, whereas the deep samples revealed no consistent difference in the band numbers between suspended and sediment trap samples.

The cluster analyses taking into account band intensity separated the samples into 2 main groups corresponding to the fjord and the Barents Sea, with the exception of 1 Barents Sea sample (Stn M1 sus- pended $200 \mathrm{~m}$ ) that clustered with the fjord samples (Fig. 3). Within the main groups, the sediment trap samples clustered according to station. In the fjord, suspended samples from the depth of maximum fluorescence clustered together with the sediment traps from 20 and $120 \mathrm{~m}$ in separate groups for June and October. The deep suspended samples (June and October) formed 1 group. The Barents Sea samples were more heterogeneous. The sediment trap samples clustered according to station and were more similar to the suspended sample from the depth of maximum fluorescence than to the deep suspended sample (Fig. 3).

\section{Relationship between community and physical environment or organic matter composition}

A CCA was used to determine how the environment influenced BCC. The model accounted for $58.3 \%$ of the total variation in the $\mathrm{BCC}$ (permutation test $\mathrm{p}=$ 0.005 ) and confirmed the importance of differentiation between water masses or location. The first CCA axis accounted for $25 \%$ of the total variation and separated the samples according to temperature and salinity, with the fjord stations being characterized by higher temperature and lower salinity than the Barents Sea stations (Fig. 4). The second axis accounted for $13 \%$ of the total variation and was mainly influenced by the POC:chl and the POC:PON ratios, but this axis re-

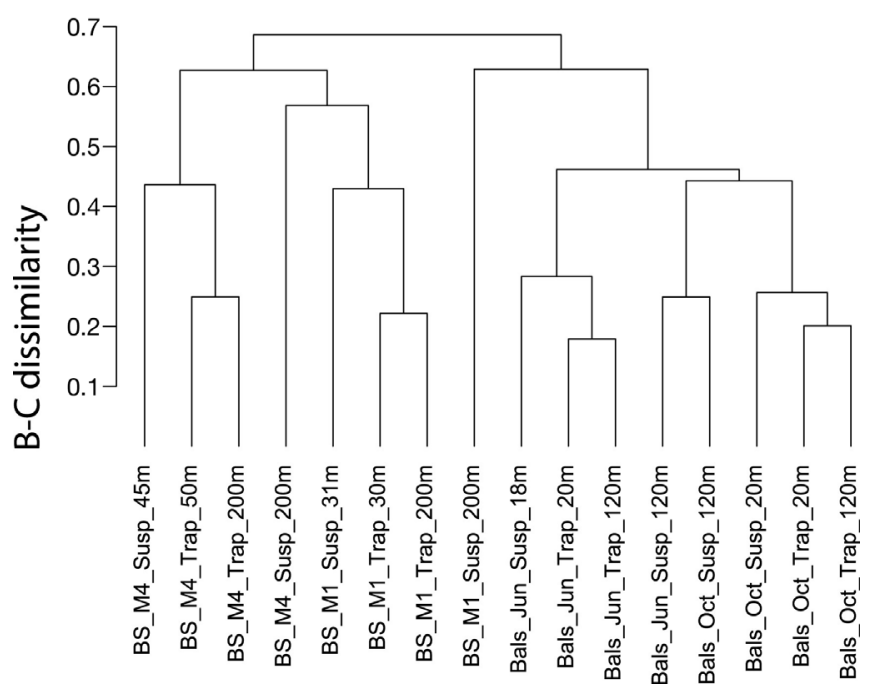

Fig. 3. Cluster dendrogram of DGGE band intensity data from the fjord and the Barents Sea. Sample names indicate region ('BS': Barents Sea, 'Bals': Balsfjord), station or month, sample type (suspended or trap), and sampling depth. The $y$-axis is the Bray-Curtis dissimilarity index (dissimilarity increasing upwards) 
vealed no obvious grouping of sampling locations or sample types (sediment traps or suspended samples). The untransformed environmental data used in the CCA are presented in Table 1.

\section{Cell-specific EEA}

Cell-specific BG and LAP varied significantly among stations both for the suspended and sediment trap samples (separate 1-way ANOVAs for substrate and sample type; all p-values $<0.001$ ) and were generally higher in the fjord than in the Barents Sea (Fig. 5). April samples from the fjord had the highest BG activity in both sample types (Tukey's tests, $\mathrm{p}<$ 0.03). LAP activities did not differ between April and June ( $p>0.05$ ) but were significantly lower in October in both sample types $(\mathrm{p}<0.05)$. Among the Barents Sea stations, rates were highest at Stn M4, where both LAP and BG activity were similar to the activity measured in the fjord in October $(p>0.05)$.

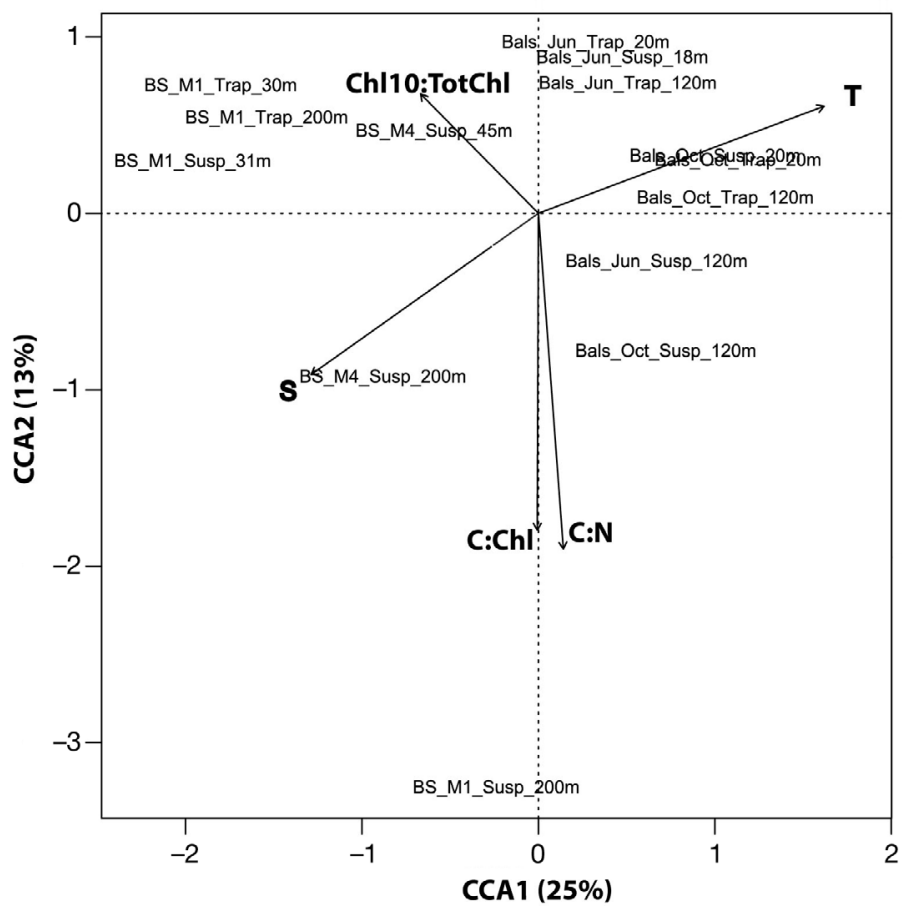

Fig. 4. Canonical correspondence analysis (CCA) biplot showing the relationship between the bacterial community composition in the different samples and environmental factors (arrows: temperature [T], salinity [S], C:N, C:chl, and chl $>10 \mu m$ :total chl ratios). Sample names specify the region (Bals: Balsfjord; BS: Barents Sea), month or station name, sample type (suspended or trap), and depth. CCA1 accounts for $25 \%$ and CCA2 for $13 \%$ of the total variation. Sediment trap samples at Stn M4 were not included in the analysis due to missing chlorophyll data
In the fjord, the sediment trap samples had significantly higher cell-specific BG than the water column samples (Fig. 5, Mann-Whitney test, $\mathrm{p}=0.01$ ). The Barents Sea stations revealed a similar trend, but the differences were not significant $(p>0.1)$. Cell-specific LAP was higher in the traps than in the water column in April in the fjord and at Stn M4 ( $p=0.01)$, whereas no difference was observed at the other stations $(\mathrm{p} \geq 0.1)$. BG and LAP were not related to $\mathrm{chl} a$ concentration, vertical flux, POC:chl or POC:PON ratios in either sample type (not shown).

\section{DISCUSSION}

The present study is among few that have investigated the BCC associated with sinking particles collected using sediment traps and the first conducted in polar regions. The sources of bacteria associated with sinking particles were inferred by comparing samples from different physical environments and by seasonal comparisons at a location where repeated sampling was performed. Based on the differences in $\mathrm{BCC}$ found among locations and seasons, the hypothesis that the sediment trap samples would reveal high similarity due to colonisation by specialised taxa was rejected. The variation in the $\mathrm{BCC}$ rather seems to reflect dominant taxa characteristic of the corresponding water masses sampled (Arctic, Atlantic and coastal/fjord water) and temporal variability, as suggested by the difference between the summer and autumn samples in the fjord. This is supported by the difference in temperature and salinity both horizontally (among stations) and vertically (shallow vs. deep samples) and was statistically confirmed by the CCA (Fig. 4).

Because the samples were not size-fractionated, free-living and particle-associated bacteria were present in both suspended and sediment trap samples. The BCC of these fractions differs to a variable degree, with macro-aggregates and marine snow hosting distinct communities (DeLong et al. 1993). While several taxa have been found both on small (1 to $60 \mu \mathrm{m})$ particles and free-living in the water column (Kellogg \& Deming 2009, Crespo et al. 2013), significant differences in the BCC were found between these fractions and aggregates $>60 \mu \mathrm{m}$ in the Laptev Sea (Arctic Ocean; Kellogg \& Deming 2009). Large, fast-sinking particles typically constitute an important part of the organic matter exported from the surface ocean, and would presumably strongly contribute to the $\mathrm{BCC}$ in sediment traps. Although not quantified in the present study, faecal 
Table 1. Composition of suspended and sinking (sediment trap samples) particulate organic matter. POC:PON is the ratio of particulate organic carbon:particulate organic nitrogen, POC:chl is the ratio of particulate organic carbon:total chlorophyll a (chl a), and Chl>10 $\mu \mathrm{m}$ :Tot chl is the proportion of chl $a$ in the size fraction $>10 \mu \mathrm{m}$ relative to the total chl a level. Sediment trap depth is given in brackets where this differed from suspended sample depth. CCA: canonical correspondence analysis

\begin{tabular}{|c|c|c|c|c|c|c|c|}
\hline \multirow{2}{*}{ Station } & \multirow{2}{*}{ Depth (m) } & \multicolumn{2}{|c|}{ POC:PON (mol:mol) } & \multicolumn{2}{|c|}{ POC:chl (wt:wt) } & \multicolumn{2}{|c|}{ Chl>10 $\mu \mathrm{m}:$ Tot chl } \\
\hline & & Suspended & Traps & Suspended & Traps & Suspended & Traps \\
\hline \multicolumn{8}{|l|}{ Balsfjord } \\
\hline April & $13(20)$ & 8.3 & 8.6 & 254 & 151 & 0.45 & 0.74 \\
\hline April & 60 & 12.5 & 9.7 & 347 & 125 & 0.75 & 0.70 \\
\hline April & 90 & 15.3 & 9.4 & 411 & 115 & 0.74 & 0.65 \\
\hline April & 120 & 15.9 & 10.6 & 703 & 133 & 0.59 & 0.67 \\
\hline June $^{a}$ & $18(20)$ & 7.82 & 9.3 & 282 & 386 & 0.50 & 0.65 \\
\hline June & 60 & 12.4 & 9.8 & 2837 & 746 & 0.15 & 0.35 \\
\hline June & 90 & 12.9 & 10.1 & 3589 & 669 & 0.18 & 0.33 \\
\hline June $^{a}$ & 120 & 12.0 & 9.6 & 3987 & 681 & 0.19 & 0.40 \\
\hline October $^{a}$ & 20 & 9.5 & 10.9 & 379 & 491 & 0.54 & 0.58 \\
\hline October & 60 & 10.8 & 13.3 & 1328 & 587 & 0.55 & 0.64 \\
\hline October & 90 & 10.3 & 10.6 & 1631 & 577 & 0.45 & 0.57 \\
\hline October $^{a}$ & 120 & 12.1 & 12.3 & 2028 & 605 & 0.33 & 0.48 \\
\hline \multicolumn{8}{|l|}{ Barents Sea } \\
\hline M1 & 20 & 7.5 & 10.1 & 172 & 578 & 0.79 & 0.68 \\
\hline $\mathrm{M1}^{\mathrm{a}}$ & $31(30)$ & 8.1 & 10.0 & 146 & 222 & 0.84 & 0.79 \\
\hline M1 & 90 & 17.3 & 12.2 & 1697 & 321 & 0.87 & 0.58 \\
\hline $\mathrm{M}^{\mathrm{a}}$ & 200 & 18.0 & 10.7 & 5571 & 308 & 0.44 & 0.64 \\
\hline M2 & 20 & 8.5 & 7.9 & 570 & 978 & 0.19 & 0.39 \\
\hline M2 & $44(50)$ & 8.3 & 8.7 & 195 & 291 & 0.14 & 0.48 \\
\hline M2 & 90 & 11.6 & 9.9 & 5214 & 726 & 0.24 & 0.02 \\
\hline M2 & 200 & 14.7 & 8.7 & 9527 & 694 & 0.28 & 0.69 \\
\hline M4 & 20 & 8.4 & 7.7 & 556 & nd & 0.38 & nd \\
\hline $\mathrm{M} 4^{\mathrm{a}}$ & $45(50)$ & 7.6 & 6.8 & 205 & nd & 0.11 & nd \\
\hline M4 & 90 & 15.1 & 7.8 & 4352 & nd & 0.41 & nd \\
\hline $\mathrm{M} 4^{\mathrm{a}}$ & 200 & 13.1 & 7.1 & 4762 & nd & 0.26 & nd \\
\hline
\end{tabular}
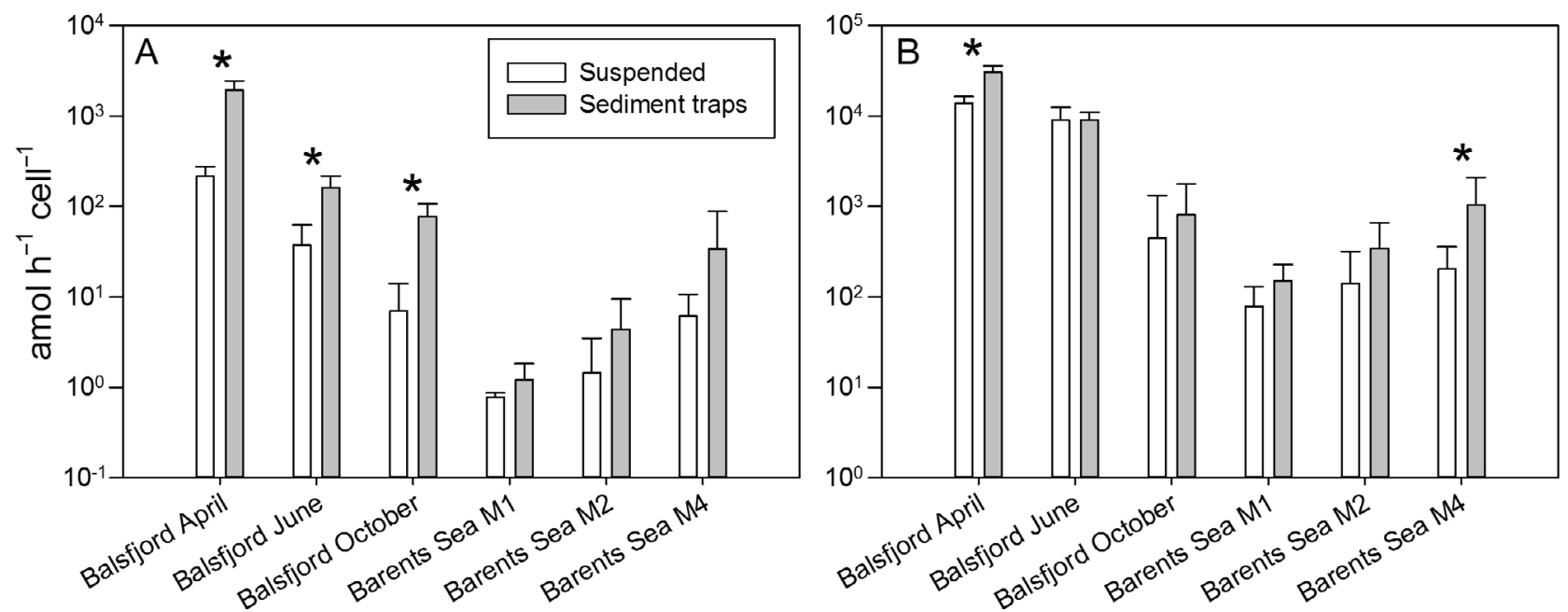

Fig. 5. Cell-specific activity of (A) $\beta$-glucosidase and (B) leucine-aminopeptidase in water column suspended samples and in sediment trap samples in the fjord (3 occasions) and in the Barents Sea (3 locations). Asterisks indicate significant differences (Mann-Whitney test, $\mathrm{p}=0.01$ ) between suspended and sediment trap samples 
pellets from calanoid copepods were present in all sediment trap samples. These pellets are typically 50 to $90 \mu \mathrm{m}$ wide and 250 to $1000 \mu \mathrm{m}$ long (Wexels Riser et al. 2002) and may account for up to $75 \%$ of exported POC in the studied regions (Wexels Riser et al. 2010). Amorphous material and marine snow appeared not to be an important fraction of the sediment trap material since sample processing was possible without severe clogging of the filters. At the depth of maximum fluorescence, both the suspended and sediment trap samples likely contained a high proportion of relatively fresh phytoplankton with associated bacteria, which would explain the high similarity in BCC between these samples. Deeper in the water column, the BCC clearly differed between the suspended and sediment trap samples. These samples also revealed large discrepancies in their biochemical composition, with higher POC:PON and POC:chl ratios of the suspended material (Table 1). The more refractory composition of suspended particles suggest longer residence time in the water column, which would have given more time for the bacterial community to develop compared to the sediment traps, which received an important input of material from the euphotic zone.

The second hypothesis, that the BCC changes during sinking, was also rejected based on the high similarity between shallow and deep traps, which again were closely related to the suspended sample from the depth of maximum fluorescence. The bacterial community rather seems to have been 'inherited' from the chlorophyll maximum, where formation of large particles takes place through aggregation of algal cells and through faecal pellet production by zooplankton (Wexels Riser et al. 2008). Peaks in bacterial fluxes at $3000 \mathrm{~m}$ depth have previously been found to correspond to peaks in POC flux, suggesting a common source in the productive surface layer (Turley \& Mackie 1995). Dominance of large phytoplankton cells in the upper water column in June and October in the fjord and at Stn M1, indicated by a high proportion $(\geq 50 \%)$ of $\mathrm{chl} a$ in the fraction $>10 \mu \mathrm{m}$, would have favoured aggregation (Table 1). Faecal pellets also occurred regularly in the sediment traps. The sinking speed of large faecal pellets is on the scale of $100 \mathrm{~m} \mathrm{~d}^{-1}$, leaving $<2 \mathrm{~d}$ for a particle to reach the deepest trap (Wexels Riser et al. 2007), which may be too little time for significant shifts in the BCC to take place. Published growth rates of attached bacteria vary considerably from $0.023 \mathrm{~d}^{-1}$ (Tang et al. 2006) to $1.8 \mathrm{~d}^{-1}$ (Grossart \& Ploug 2001). The lower value would only result in a $5 \%$ increase in the resident bacterial population size over $2 \mathrm{~d}$.
Even with higher bacterial growth rates, Kiørboe et al. (2004) found that grazing losses to flagellates were more important in controlling bacterial populations on aggregates than bacterial growth. Changes in the BCC on sinking particles due to growth of the resident population are therefore likely negligible in the relatively shallow $(<300 \mathrm{~m})$ environments investigated here. In abyssal areas, the longer transit time for particles from the euphotic zone to the mesopelagic and deep sea would probably favour succession of bacterial communities on sinking particles. Rapid colonisation of newly formed particles and their subsequent export to the mesopelagic was also proposed by Ghiglione et al. (2007) based on diel and seasonal sampling of free-living and particle-associated bacteria in the Mediterranean Sea. Earlier investigations also demonstrated the importance of aggregates for flux of bacteria to the deep sea (Turley \& Mackie 1994). The present findings are therefore consistent with colonisation processes found outside the Arctic. Because certain bacterial groups possess traits for attachment to surfaces, such as motility and synthesis of extracellular polysaccharides (González et al. 2008, Grossart 2010), sinking particles may further provide a selective force for bacteria in the ambient water column.

The maximum cell-specific EEA exceeded those from other more oligotrophic parts of the Arctic Ocean, such as the Northeast Water Polynya (Vetter \& Deming 1994) and the East Beaufort Sea (Kellogg et al. 2011), by orders of magnitude. Cell-specific EEA was also higher than in the North Water Polynya (W Greenland; Huston \& Deming 2002), a region with new production comparable to that of the Barents Sea (Tamelander et al. 2013), but mostly at the same order of magnitude. It was not evaluated whether the difference in incubation volume $(5 \mathrm{ml}$ in the case of the Barents Sea and $0.4 \mathrm{ml}$ in the fjord) affected EEA. Cell-specific EEAs were generally higher in the fjord than in the Barents Sea, but this may also be related to the higher temperature and, conceivably, higher abundance of organic matter in the fjord than in the open sea. It should be noted that because no attempt was made to dislodge bacteria from particles, the BA estimates are likely conservative, and this would have inflated the cell-specific EEA values.

Although no distinction between free-living and particle-associated bacteria was made in the present study, it was assumed that the fraction of bacteria associated with particles was higher in the sediment traps than in the water column. Cell-specific EEA was therefore expected to be higher in the sediment 
trap samples. This was partially supported by the present results: the cell-specific BG in the fjord was significantly higher at all 3 sampling occasions, and a similar trend, albeit not statistically significant, was also present in the Barents Sea (Fig. 5). Cell-specific LAP tended to be higher in the sediment traps, but only 2 stations revealed a significant difference between the sample types. Differences in activity may have been related to community composition (Sala et al. 2008), but because BCC only differed between suspended and sediment trap samples at the greater sampling depths, other factors likely contributed to the observed pattern. Aggregation may have caused an increase in metabolic activity, as bacteria have been shown to up-regulate their protease activity within $2 \mathrm{~h}$ following attachment to artificial aggregates (Grossart et al. 2007). Differences in the composition of suspended and sinking organic matter may further have contributed to maintaining a high activity of bacteria in sediment traps. While the quality of the suspended material decreased with depth, indicated by increasing C:N and POC:chl ratios, the sediment traps revealed a more uniform composition of the settled material (Table 1). Below $60 \mathrm{~m}$ depth, the sinking material had consistently lower $\mathrm{C}: \mathrm{N}$ and POC:chl ratios than the suspended material. The more labile composition of sinking material deeper in the water column may therefore have sustained the somewhat higher enzyme activities of bacteria in the sediment traps.

While the present study is based on a limited number of observations, it demonstrates that the composition of the bacterial community associated with exported organic matter varies among water masses, reflecting the community present in the surface layer. The present observations also support the view that particle colonisation in the surface layer and subsequent vertical export provides an input of bacteria to deeper water layers (Turley \& Mackie 1995, Ghiglione et al. 2007). Future attempts to evaluate the metabolic activity and community composition of bacteria associated with sinking particles would benefit from quantifying the abundance of free and attached bacteria separately and from molecular taxonomical tools with higher resolution than DGGE, such as direct sequencing.

Acknowledgements. I kindly thank J. M. Gasol for making lab facilities available and for helpful comments on the manuscript. M. Reigstad coordinated the field campaigns and provided the POC, PON and chlorophyll data, V. Balagué guided me in DNA extraction and DGGE analyses, and R. Primicerio provided advice on statistical analyses; their support is gratefully acknowledged. The crews of RV 'Johan
Ruud' and RV 'Helmer Hansen' are thanked for assistance during sampling. I kindly thank 3 anonymous reviewers for their constructive comments on the manuscript. The present study was funded by Tromsø forskningsstiftelse through the project CONFLUX, by the Research Council of Norway through the project MERCLIM (Nr. 184860/S30), and by the European Commission's 7th FP through the project BacPac (Marie Curie Actions, No. 297849).

\section{LITERATURE CITED}

Amacher J, Neuer S, Lomas M (2013) DNA-based molecular fingerprinting of eukaryotic protists and cyanobacteria contributing to sinking particle flux at the Bermuda Atlantic time-series study. Deep-Sea Res II, doi:10.1016/ j.dsr2.2013.01.001

Baltar F, Aristegui J, Gasol JM, Sintes E, van Aken HM, Herndl GJ (2010) High dissolved extracellular enzymatic activity in the deep central Atlantic Ocean. Aquat Microb Ecol 58:287-302

Crespo BG, Pommier T, Fernández-Gómez B, Pedrós-Alió C (in press) (2013) Taxonomic composition of the particle attached and free-living bacterial assemblages in the Northwest Mediterranean Sea analyzed by pyrosequencing of the $16 \mathrm{~S}$ rRNA. MicrobiologyOpen, doi: $10.1002 / \mathrm{mbo} .92$

> DeLong EF, Franks DG, Alldredge AL (1993) Phylogenetic diversity of aggregate-attached vs. free-living marine bacterial assemblages. Limnol Oceanogr 38:924-934

Ditchfield AK, Wilson ST, Hart MC, Purdy KJ, Green DH, Hatton AD (2012) Identification of putative methylotrophic and hydrogenotrophic methanogens within sedimenting material and copepod faecal pellets. Aquat Microb Ecol 67:151-160

Eilertsen HC, Skardhamar J (2006) Temperatures of north Norwegian fjords and coastal waters: variability, significance of local processes and air-sea heat exchange. Estuar Coast Shelf Sci 67:530-538

> Ghiglione JF, Mevel G, Pujo-Pay M, Mousseau L, Lebaron P, Goutx M (2007) Diel and seasonal variations in abundance, activity, and community structure of particleattached and free-living bacteria in NW Mediterranean sea. Microb Ecol 54:217-231

> González JM, Fernández-Gómez B, Fernández-Guerra A, Gómez-Consarnau L and others (2008) Genome analysis of the proteorhodopsin-containing marine bacterium Polaribacter sp. MED152 (Flavobacteria). Proc Natl Acad Sci USA 105:8724-8729

Grossart HP (2010) Ecological consequences of bacterioplankton lifestyles: changes in concepts are needed. Environ Microbiol Rep 2:706-714

> Grossart HP, Ploug H (2001) Microbial degradation of organic carbon and nitrogen on diatom aggregates. Limnol Oceanogr 46:267-277

> Grossart HP, Tang KW, Kiørboe T, Ploug H (2007) Comparison of cell-specific activity between free-living and attached bacteria using isolates and natural assemblages. FEMS Microbiol Lett 266:194-200

> Holm-Hansen O, Riemann B (1978) Chlorophyll a determination -improvements in methodology. Oikos 30:438-447

Hoppe HG (1983) Significance of exoenzymatic activities in the ecology of brackish water: measurements by means of methylumbelliferyl-substrates. Mar Ecol Prog Ser 11: 299-308 
Huston AL, Deming JW (2002) Relationships between microbial extracellular enzymatic activity and suspended and sinking particulate organic matter: seasonal transformations in the north water. Deep-Sea Res II 49: 5211-5225

Jing HM, Shek L, Yung WY, Jin XW, Liu HB (2012) Dynamics of bacterial community composition during degradation of copepod fecal pellets. J Plankton Res 34:700-710

Karl DM, Tilbrook BD (1994) Production and transport of methane in oceanic particulate organic matter. Nature 368:732-734

Kellogg CTE, Deming JW (2009) Comparison of free-living, suspended particle, and aggregate-associated bacterial and archaeal communities in the Laptev Sea. Aquat Microb Ecol 57:1-18

Kellogg CTE, Carpenter SD, Renfro AA, Sallon A, Michel C, Cochran JK, Deming JW (2011) Evidence for microbial attenuation of particle flux in the Amundsen Gulf and Beaufort Sea: elevated hydrolytic enzyme activity on sinking aggregates. Polar Biol 34:2007-2023

Kiørboe T, Grossart HP, Ploug H, Tang K (2002) Mechanisms and rates of bacterial colonization of sinking aggregates. Appl Environ Microbiol 68:3996-4006

Kiørboe T, Tang K, Grossart HP, Ploug H (2003) Dynamics of microbial communities on marine snow aggregates: colonization, growth, detachment, and grazing mortality of attached bacteria. Appl Environ Microbiol 69:3036-3047

Kiørboe T, Grossart HP, Ploug H, Tang K, Auer B (2004) Particle-associated flagellates: swimming patterns, colonization rates, and grazing on attached bacteria. Aquat Microb Ecol 35:141-152

Loeng H (1991) Features of the physical oceanographic conditions of the Barents Sea. Polar Res 10:5-18

Marty D, Nival P, Yoon WD (1997) Methanoarchaea associated with sinking particles and zooplankton collected in the northeastern tropical Atlantic. Oceanol Acta 20: 863-869

Muyzer G, Brinkhoff T, Nübel U, Santegoeds C, Schäfer H, Wawer C (1997) Denaturing gradient gel electrophoresis (DGGE) in microbial ecology. In: Akkermans ADL, van Elsas JD, de Bruijn FJ (eds) Molecular microbial ecology manual. Kluwer Academic, Dordrecht, p 1-27

> Reigstad M, Wexels Riser C, Wassmann P, Ratkova T (2008) Vertical export of particulate organic carbon: attenuation, composition and loss rates in the northern Barents Sea. Deep-Sea Res II 55:2308-2319

- Wexels Riser C, Wassmann P, Olli K, Pasternak A, Arashkevich E (2002) Seasonal variation in production, retention and export of zooplankton faecal pellets in the marginal ice zone and central Barents Sea. J Mar Syst 38:175-188

- Wexels Riser C, Reigstad M, Wassmann P, Arashkevich E, Falk-Petersen S (2007) Export or retention? Copepod abundance, faecal pellet production and vertical flux in the marginal ice zone through snap shots from the northern Barents Sea. Polar Biol 30:719-730

Editorial responsibility: Eva Lindström, Uppsala, Sweden
Wexels Riser C, Wassmann P, Reigstad M, Seuthe L (2008) Vertical flux regulation by zooplankton in the northern Barents Sea during Arctic spring. Deep-Sea Res II 55: 2320-2329

- Wexels Riser C, Reigstad M, Wassmann P (2010) Zooplankton-mediated carbon export: a seasonal study in a northern Norwegian fjord. Mar Biol Res 6:461-471

Sala MM, Terrado R, Lovejoy C, Unrein F, Pedros-Alio C (2008) Metabolic diversity of heterotrophic bacterioplankton over winter and spring in the coastal arctic ocean. Environ Microbiol 10:942-949

Smith DC, Simon M, Alldredge AL, Azam F (1992) Intense hydrolytic enzyme-activity on marine aggregates and implications for rapid particle dissolution. Nature 359: 139-142

Spilling K, Kremp A, Tamelander T (2006) Vertical distribution and cyst production of Peridiniella catenata (Dinophyceae) during a spring bloom in the Baltic Sea. J Plankton Res 28:659-665

Sundfjord A, Fer I, Kasajima Y, Svendsen H (2007) Observations of turbulent mixing and hydrography in the marginal ice zone of the Barents Sea. J Geophys Res 112: C05008, doi:10.1029/2006JC003524

Tamburini C, Goutx M, Guigue C, Garel M and others (2009) Effects of hydrostatic pressure on microbial alteration of sinking fecal pellets. Deep-Sea Res II 56: 1533-1546

> Tamelander T, Aubert AB, Wexels Riser C (2012) Export stoichiometry and contribution of copepod faecal pellets to vertical flux of particulate organic carbon, nitrogen and phosphorus. Mar Ecol Prog Ser 459:17-28

Tamelander T, Reigstad M, Olli K, Slagstad D, Wassmann P (2013) New production regulates export stoichiometry in the ocean. PLoS ONE 8:e54027

Tammert H, Olli K, Sturluson M, Hodal H (2008) Bacterial biomass and activity in the marginal ice zone of the northern Barents Sea. Deep-Sea Res II 55:2199-2209

Tang KW, Grossart HP, Yam EM, Jackson GA, Ducklowl HW, Kiørboe T (2006) Mesocosm study of particle dynamics and control of particle-associated bacteria by flagellate grazing. Mar Ecol Prog Ser 325:15-27

> Turley CM, Mackie PJ (1994) Biogeochemical significance of attached and free-living bacteria and the flux of particles in the NE Atlantic Ocean. Mar Ecol Prog Ser 115: 191-203

> Turley CM, Mackie PJ (1995) Bacterial and cyanobacterial flux to the deep NE Atlantic on sedimenting particles. Deep-Sea Res I 42:1453-1474

Vetter YA, Deming JW (1994) Extracellular enzyme-activity in the arctic northeast water polynya. Mar Ecol Prog Ser 114:23-34

Wassmann P, Hansen L, Andreassen IJ, Wexels Riser C, Urban-Rich J (1999) Distribution and sedimentation of faecal pellets on the Nordvestbanken shelf, northern Norway, in 1994. Sarsia 84:239-252

Submitted: March 18, 2013; Accepted: May 16, 2013 Proofs received from author(s): June 20, 2013 